\title{
Comparative Analysis of Farmers' Livelihood Strategies by Optimizing Resource Use in Farming Areas of Adamawa State, Nigeria and Eastern Uttar Pradesh, India: An Application of Sen's Multi-Objectve Programming Approach
}

\author{
${ }^{1}$ O. Gwandi ${ }^{1, *},{ }^{2}$ M. K. James, and ${ }^{3}$ Y. Z. Dia \\ ${ }^{1}$ Department of Agricultural Technology \\ Federal Polytechnic, Mubi, Adamawa State, Nigeria \\ ${ }^{2}$ National Identity Management Commission, \\ Yola, Adamawa State, Nigeria \\ ${ }^{3}$ Adamawa State College of Agriculture, \\ Ganye, Nigeria \\ *Corresponding author's email: godoffer2010 [AT] gmail.com
}

\begin{abstract}
This paper explores the likelihoods of optimal allocation of resources as livelihood strategies for the farmers in Eastern Uttar Pradesh, India and Adamawa State, Nigeria. The study compared and determined the best production plan and resource allocation among food crop farmers in the two location of the study area Eastern Uttar Pradesh and Adamawa State, Nigeria. The objective of the study was to examine the socio-economic characteristics of food crop famers and to formulate alternative farm plans for improving farm economy. A multistage random sampling technique was used to select a total of 300 food crop farmers, the data for the study were randomly collected from 150 farmers from the eight district of Varanasi District of Eastern Uttar Pradesh and 150 from eight villages of the 21 local government area of Adamawa state. Structured questionnaire survey was used to obtained data from the respondents in the study area. Descriptive statistics and Sen's Multi-Objective Programming (MOP) Model was used to analyze the data obtained from the field survey. The study shows that in Eastern Uttar Pradesh and Adamawa State, majority 96\% and $68.7 \%$ were full time farmers with average mean of 46.5 and 31 years of age respectively. They had average agricultural farming experience of 27 years for farmers in Uttar Pradesh and 30.96 years of farming experience for farmers in Adamawa State Nigeria. Majority (94\%) Eastern Uttar Pradesh and (85.3\%) Adamawa State were male farmers and only $18.7 \%$ in Uttar Pradesh and 15.3\% of the respondent had no formal education with average land holding of 0.73 (Uttar Pradesh) and 3.1 (Adamawa State) hectares. The result of the multiple objective programming reveals that the existing average income of ₹581 68 (Uttar Pradesh) and ₹69348.97(Adamawa State) was realized while the optimal income obtained from the multi-objective programming was ₹61251.40 Uttar Pradesh and ₹71979.95 Adamawa State which is 5.30 and 3.79 per cent higher over present income respectively. Consequently, for employment, the existing plan was 80.92 man days for Uttar Pradesh and 156.5 man days for Adamawa State while the optimal plan for the maximization of employment recommends 81.32 man days which represent 0.49 per cent increase for Uttar Pradesh and 162 man days which represent 3.51per cent increase for Adamawa State. Lastly for the minimization of fertilizer the existing plan allocated $218.97 \mathrm{~kg}$ for farmers in Uttar Pradesh and $282.15 \mathrm{~kg}$ for farmers in Adamawa State offertilizer while the optimalplan for minimization offertilizer use recommends $204 \mathrm{~kg}$ Uttar Pradesh and 218.03 $\mathrm{kg}$ Adamawa State which represents a decrease of 6.83 per cent and 22.73 per cent respectively. It is recommended among others that the food crop farmers be educated on allocation of resources for optimum utilization to raise their level of production and income for a better livelihood.
\end{abstract}

Keywords--- Farmers' Livelihood Strategies, Opimising resource use, Sen’s Multiobjective Programming

\section{INTRODUCTION}

Livelihood strategies reflect range and combinations of activities and alternatives that people make to achieve goals and livelihoods. Livelihood strategies evolve according to implicit and / or explicit decision-making foundation on the intemal and external verity of livelihood. Subsistence s trategies are diverse and are in a constant process of change and adaptation. An efficient agricultural sy stem aims to develop optimal combinations in enterprises for greater integration of agricultural activities. In order to make better use of the agricultural lands, in order to support farmers' families and produce crops in a sustainable way, agricultural planning must be carefully organized at farmlevel. Mostfarmers build a diversified portfolio of social support activities and survival skills to raise living standard. They grow more crops in a season to meet the needs 
of family consumption along with generating sufficient income for other household expenses. Therefore, improving farmers' income is an important consideration for the formulation of alternative business plans. Farmers use high-dose chemical fertilizers with less use of organic fertilizers in crops that are not suitable for soil health (Ku shwaha, 1998a). The reduction in the use of chemical fertilizers becomes the second goal for agricultural planning. It is also desirable to offer more job opportunities for rural workers. The third objective of agricultural planning is to increase the use of labor in crop cultivation. Therefore, this study attempt to formulate alternative farm plans to increase income and employment by reducing the use of fertilizers i $n$ farms of Varanasi Uttar Pradesh, India using Sen's MOP method (Sen, 1983). This paper aims to examine the socioeconomic characteristics of food crop framers and formulate alternative farm plans for improving farm economy that will consequently have positive impact on their livelihood strategies. This method has been used successfully by many researchers (Sen and Painuli 1984, Kushwaha $1992 \mathrm{~b}$, Memariani, 1993, Sen and Dubey 1994, Gangwar 1994, Singh 2002, Kumar 2012, Gautam 2015, Kumari et al. 2017) to formulate the right farming plan to achieve multiple goals at the same time.

\section{Sampling procedure and Data Collection}

\section{METHODOLOGY}

The study was conducted in Varanasi dis trict of Uttar Pradesh which comprises of 8 blocks. Multi-stage random sampling technique was employed in the selection of res pondents in this State. In the first stage one block was selected purposively. In the second stage one village was selected randomly in each of the selected block to give a total of 8 sampled villages. The third stage sampling involved the random selection of 150 farmers in the 8 villages.

Primary data was used for the study, which was obtained through the administration of questionnaire to farmers in the sampled villages with the assistance of trained personnel. The data collected was for 2016 and 2017 farming seasons.

\section{Methods of Data Analysis}

Inferential statis tic was used to analyse the data. Sen's (1983) Multi-objective programming was used to achieve the optimumutilization and res ource allocation of farmers' in the study area. Linear Programming model is described as:

$$
\begin{aligned}
& \text { Maximize } Z 1=\sum_{j=1}^{n} I_{j} X_{j} \\
& \text { Maximize } Z 2=\sum_{j=1}^{n} E_{j} X_{j} \text {, and } \\
& \text { Minimize } Z 3=\sum_{j=1}^{n} F_{j} X_{j}
\end{aligned}
$$

Subject to the constraints,

$x_{j} \geq 0$

$$
\sum_{j=1}^{n} a_{i j} x_{j} \geq=\leq b_{i}
$$

Where,

$\mathrm{Z}_{1}=$ Total net returns fromall the crops in rupees

$\mathrm{Z}_{2}=$ Total employment on the farmin man days and

$\mathrm{Z}_{3}=$ Total fertilizer use on the farmin $\mathrm{Kg}$.

$\mathrm{I}_{\mathrm{j}}=$ Net return from $\mathrm{j}^{\text {th }}$ crop in rupees $/ \mathrm{ha}$.

$E_{j}=$ Employment of $j$ crop in man-days/ha

$\mathrm{F}_{\mathrm{j}}=$ Fertilizer use in $\mathrm{j}$ crop in $\mathrm{kg} / \mathrm{ha}$

$\mathrm{X}_{\mathrm{j}}=$ Area under $\mathrm{j}^{\text {th }}$ crop in ha.

$\mathrm{a}_{\mathrm{ij}}=$ Quantity/Number of $\mathrm{i}^{\text {th }}$ in put required per hectare by $\mathrm{j}^{\text {th }}$ crop.

$\mathrm{b}_{\mathrm{i}}=$ Quantity/Number av ailable of the $\mathrm{i}^{\mathrm{th}}$ res ource/ Input

The individual optimization of income, employment and fertilizer use have generated three different cropping pattems with high degree of conflicts in achievement of the objectives. To overcome this problemand generating an appropriate farming sys tem that achieves all the three objectives simultaneously, Sen's MOP method (Sen 1983) was us ed. Sen's MOP method is described as below:

$$
\text { Maximize } Z^{*}=\frac{\sum_{j=1}^{n} I_{j} X_{j}}{W_{1}}+\frac{\sum_{j=1}^{n} E_{j} X_{j}}{W_{2}}-\frac{\sum_{j=1}^{n} F_{j} X_{j}}{W_{3}}
$$

Subject to the constraints, 
$x_{j} \geq 0 \mathrm{i}=1,2, \ldots$ $., m j=1,2, \ldots . ., n$

$$
\sum_{j=1}^{n} a_{i j} x_{j} \geq \leq b_{i}
$$

Where, $\mathrm{Z}^{*}=$ Multi Objective Function, $\mathrm{W}_{1}=$ Maximum Income, $\mathrm{W}_{2}=$ Maximum Employment and $\mathrm{W}_{3}=$ Minimum

Fertilizer use.

\section{Formulation of Optimal Farm plans:}

\section{RESULTS AND DISCUSSION}

The alternative farmplans havebeen formulated increasing the income of the farmers with more employment opportunities with les ser use of fertilizer. The optimization model is des cribed as below;

$\mathrm{Max}_{1}=\mathrm{X}_{1}+\mathrm{X}_{2}$

The decision variables are:

$\mathrm{X}_{1}=$ area allocated for paddy crop, $\mathrm{X}_{2}=$ area allocated for maize crop, $\mathrm{X}_{3}=$ area allocated for redgram crop, $\mathrm{X}_{4}=\operatorname{area}$ allocated for blackgram crop, $\mathrm{X}_{5}=$ area allocated for wheat crop, $\mathrm{X}_{6}=$ area allocated for pea crop, $\mathrm{X}_{7}=$ area allocated for gram crop, $\mathrm{X}_{8}=$ labour hiring, $\mathrm{X}_{9}=$ capital borrowing

Subject to:

\section{Res ource cons traints}

a. Kharif land (0.73 ha),

b. Rabi land (0.73 ha)

c. Kharif labour(120 man-days)

d. Rabi labour(130 man-days)

e. Wage rate (Rs.300 man-days)

f. Rate of interest on borrowings (4\% p.a)

g. Kharif own capital(Rs.31500)

h. Rabi own capital (Rs.31500)

Temporally-Ordered Routing Alg orithm(TORA) computer based software was used to obtain theoptimumland allocation area for food crop farmers.

The optimal farmplan generated for maximizing income, employment and minimizing fertilizer use is presented in Table 1 and this is based on the as sumption that maximization of income, employment maximization and minimization of fertilizer use is the underlying behavioral principle guiding the farmers in their resource use and allocation decision. The Table shows that the exis ting average income of ₹ 58168.5 was realized while the optimal income obtained fromthe multiobjective programming output is ₹ 61251.40 which represent 5.30 per cent enhancement in income. This results reveals that the farmers in the study area were already working close to the efficiency levelas there is only a marginal variation between the existing and the alternative suggested plan. Consequently, for employment, the existing plan was 80.92 man days while the optimal plan for the maximization of employment recommends 81.32 man days which represent 0.49 per cent increase. Lastly for the minimization of fertilizer the exis ting plan allocated $218.97 \mathrm{~kg}$ of fertilizer while the optimal plan for minimization of fertilizer use recommends $204 \mathrm{~kg}$ which represent a marginal decrease of 6.83 per cent.

Table 1: Results of Exis ting and Alternative Plans of Income, Employment and Fertilizer use of farmers in Uttar Pradesh farms

\begin{tabular}{|c|c|c|c|c|c|}
\hline \multirow[b]{2}{*}{ Particulars } & \multirow[b]{2}{*}{$\begin{array}{l}\text { Existing } \\
\text { plan }\end{array}$} & \multicolumn{3}{|c|}{ Individual Optimization } & \multirow[b]{2}{*}{ Sen's M.O.P. } \\
\hline & & $\begin{array}{l}\text { Max. } \\
\text { Income }\end{array}$ & $\begin{array}{l}\text { Max. } \\
\text { Employment }\end{array}$ & $\begin{array}{l}\text { Min. } \\
\text { Fertilizer }\end{array}$ & \\
\hline Income (₹) & 58168.5 & $\begin{array}{l}\text { 62306.37 } \\
(+7.11)\end{array}$ & $\begin{array}{l}57472.05 \\
(-1.19)\end{array}$ & $\begin{array}{l}41009.94 \\
(-29.49)\end{array}$ & $\begin{array}{l}61251.40 \\
(+5.30)\end{array}$ \\
\hline $\begin{array}{l}\text { Employment } \\
\text { (Man-days) }\end{array}$ & 80.92 & $\begin{array}{l}77.52 \\
(-4.20)\end{array}$ & $\begin{array}{l}83.82 \\
(+3.58)\end{array}$ & $\begin{array}{l}52.36 \\
(-35.29)\end{array}$ & $\begin{array}{l}81.32 \\
(0.49)\end{array}$ \\
\hline Fertilizer use (Kg) & 218.97 & $\begin{array}{l}204.84 \\
(-6.45)\end{array}$ & $\begin{array}{l}228.48 \\
(4.34)\end{array}$ & $\begin{array}{l}202.45 \\
(-7.54)\end{array}$ & $\begin{array}{l}204 \\
(-6.83)\end{array}$ \\
\hline
\end{tabular}

Source: Field Survey 2017

Note: Figures in parentheses shows the percentage increase/decrease over the existing levels.

Table 2 reveals the optimal farm plan generated for maximizing income, employment and minimizing fertilizer use and this is based on the assumption that maximization of income, employment maximization and minimization of fertilizer use is the underlying behavioral principle guiding the farmers in their resource use and allocation decision. The table shows that the existing average income of ₹ 69348.97 was realized while the optimal income obtained from the multi-objective programming output is ₹ 71979.95 which represent 3.79 per cent enhancement in income. This results reveals that the 
farmers in the study area were already working close to the efficiency level as there is only a marginal variation between the exis ting and the alternative suggested plan. Consequently, for employment, the exis ting plan was 156.5 man days while the optimal plan for the maximization of employment recommends 162 man days which represent 3.51 percent increase. Lastly for the minimization of fertilizer the existing plan allocated $282.15 \mathrm{~kg}$ of fertilizer while the optimal plan for minimization of fertilizer use recommends $218.3 \mathrm{~kg}$ which represent a marginal decrease of 22.73 per cent.

Table 2: Results of Exis ting and Alternative Plans of Income, Employment and Fertilizer use of farmers in Nigeria farms

\begin{tabular}{|c|c|c|c|c|c|}
\hline \multirow[b]{2}{*}{ Particulars } & \multirow[b]{2}{*}{ Exis ting plan } & \multicolumn{3}{|c|}{ Individual Optimization } & \multirow[b]{2}{*}{ Sen's M.O.P. } \\
\hline & & $\begin{array}{l}\text { Max. } \\
\text { Income }\end{array}$ & $\begin{array}{l}\text { Max. } \\
\text { Employment }\end{array}$ & $\begin{array}{l}\text { Min. } \\
\text { Fertilizer }\end{array}$ & \\
\hline Income (Rs.) & 69348.97 & $\begin{array}{l}74281.09 \\
(+7.11)\end{array}$ & $\begin{array}{l}60772.05 \\
(-12.37)\end{array}$ & $\begin{array}{l}51147.65 \\
(-26.25)\end{array}$ & $\begin{array}{l}71979.95 \\
(+3.79)\end{array}$ \\
\hline $\begin{array}{l}\text { Employment } \\
\text { (Man-days) }\end{array}$ & 156.5 & $\begin{array}{l}129.25 \\
(-17.41)\end{array}$ & $\begin{array}{l}167.75 \\
(+7.19)\end{array}$ & $\begin{array}{l}148 \\
(-5.43)\end{array}$ & $\begin{array}{l}162 \\
(+3.51)\end{array}$ \\
\hline $\begin{array}{l}\text { Fertilizer use } \\
\text { (kg.) }\end{array}$ & 282.15 & $\begin{array}{l}263.80 \\
(-6.50)\end{array}$ & $\begin{array}{l}287.30 \\
(+1.83)\end{array}$ & $\begin{array}{l}209.30 \\
(-25.82)\end{array}$ & $\begin{array}{l}218.03 \\
(-22.73)\end{array}$ \\
\hline
\end{tabular}

Source: Field Survey 2017

Note: Figures in parentheses shows the percentage increase/decrease over the existing levels.

The percentage allocation of exis ting cropping pattern along with the MOP percentage efficient recommended cropping pattern if the farmers in the study area are to enhance their income by reallocating the existing plan to adopt the MOP recommended efficient best technology and management practice. In Table 3 the result reveals that the efficient cropping pattern that enhances the income of the farmers is by reducing the area under paddy from $0.52 \mathrm{ha}$ which repres ents $71.23 \%$ of the total land earlier allocated to 0.42 ha i.e.57.53\%. Similarly for maize from 0.10 ha (13.7\%) to 0.02 ha $(2.74 \%)$ and increase the area under Redgramfrom 0.06 ha $(8.22 \%)$ and Black gram 0.05 ha (i.e $6.85 \%)$ to 0.10 ha $(13.70 \%)$ and 0.19 ha $(26 \%)$ respectively. Consequently, the existing plan during the rabbi session allocated 0.62 ha (84.93\%) while MOP recommended a reduction to 0.56 ha (i.e. $76.71 \%$ ), for pea the existing plan allocated $0.07(9.59 \%$ ) ha while the MOP recommended that the allocation be increase to $0.10(13.70 \%)$ ha and for gramfrom $0.04(5.48 \%)$ ha should be increase to 0.70 ha which represents $9.59 \%$.

Table 3: Percentage Change of Existing and Optimal Plan on food crop farms in Uttar Pradesh

\begin{tabular}{lllll}
\hline Crops & $\begin{array}{l}\text { Exis ting plan } \\
\text { Area (ha) }\end{array}$ & Percentage & $\begin{array}{l}\text { Optimal plan } \\
\text { Area(ha) }\end{array}$ & Percentage \\
\hline Kharif seas on & & & & \\
Paddy & 0.52 & 71.23 & 0.42 & 57.53 \\
Maize & 0.10 & 13.70 & 0.02 & 2.74 \\
Redgram & 0.06 & 8.22 & 0.10 & 13.70 \\
Blackgram & 0.05 & 6.85 & 0.19 & 26.03 \\
Total & $\mathbf{0 . 7 3}$ & $\mathbf{1 0 0}$ & $\mathbf{0 . 7 3}$ & $\mathbf{1 0 0}$ \\
Rabi seas on & & & & 76.71 \\
Wheat & 0.62 & 84.93 & 0.56 & 13.70 \\
Pea & 0.07 & 9.59 & 0.10 & 9.59 \\
Gram & 0.04 & 5.48 & 0.07 & $\mathbf{1 0 0}$ \\
Total & $\mathbf{0 . 7 3}$ & $\mathbf{1 0 0}$ & $\mathbf{0 . 7 3}$ & \\
\hline
\end{tabular}

Source: Field Survey 2017

Table 4 presents the percentage allocation of existing cropping pattern along with the MOP percentage efficient recommended cropping pattern if the farmers in the study area are to enhance their income by reallocating the existing plan to adopt the MOP recommended efficient best technology and management practice. The table reveals that the efficient cropping pattern that enhances the income of the farmers is by reducing the area under maize from $1.13 \mathrm{ha}$ which represents $36.33 \%$ of the total land earlier allocated to 0.56 ha i.e. $18.01 \%$. Similarly decrease area for paddy from $0.47 \mathrm{ha}(15.11 \%)$ to 0.41 ha $(13.18 \%)$ and the area under sorghum from 0.36 ha $(11.58 \%)$ to 0.41 ha $(13.18 \%)$ and 0.23 ha $(7.40 \%)$ respectively. Consequently, the existing plan for groundnut allocated 0.35 ha $(11.25 \%)$ while MOP recommended the same plan, for cowpea the exis ting plan allocated $0.80(25.72 \%)$ ha while the MOP recommended that the allocation be increase to $1.56(50.16 \%)$ ha. This agrees with Kushwaha (1996) in their study of estimation of hectarage response of irrigated tomato to some selected economic factors in Bauchi State, Nigeria. 
Table 4: Percentage Change of Existing and Optimal Plan on food crop farms in Nigeria

\begin{tabular}{lllll}
\hline Crops & $\begin{array}{l}\text { Exis ting plan } \\
\text { Area (ha) }\end{array}$ & Percentage & $\begin{array}{l}\text { Optimal plan } \\
\text { Area(ha) }\end{array}$ & Percentage \\
\hline Maize x1 & 1.13 & 36.33 & 0.56 & 18.01 \\
Paddy x2 & 0.47 & 15.11 & 0.41 & 13.18 \\
Sorghum 33 & 0.36 & 11.58 & 0.23 & 7.40 \\
Groundnut $x 4$ & 0.35 & 11.25 & 0.35 & 11.25 \\
Cowpea x5 & 0.80 & 25.72 & 1.56 & 50.16 \\
Total & $\mathbf{3 . 1 1}$ & $\mathbf{1 0 0}$ & $\mathbf{3 . 1 1}$ & $\mathbf{1 0 0}$ \\
\hline
\end{tabular}

Source:Field Survey 2017

\section{CONCLUTION AND RECOMMENDATIONS}

This study revealed that male dominated the farming activities in the study area and majority of them were small and marginal farmers within the middle age group. The study als o revealed that most of the respondents are married with s mall family size and majority of them were educated with years of farming experience. It was revealed als o fromthe result that most of them were farmers. The findings from the results also reveals that majority of the farmers had no extension visit and their land acquis ition is based on inheritance. Both family and hired labor is the major source of labor in the study area.

The result of the multiple objective programming reveals that the farmers in the study area were already working close to the efficiency level as there is only a marginal variation between the existing and the alternative suggested plan. Based on this findings, the following recommendation are made:

1. The need to support the farmers with the extension service for better subsistence strategies cannot be underestimated. Therefore, it is recommended that extension services be modernized and strengthened through appropriate governmental and non-governmental funding. This will help and encourage extension workers to educate farmers about the allocation of critical resources and managerial skills that will enable farmers to plan and evaluate commercial activities on farms for better standard of living.

2. There is need to educate the farmers on how to utilize their limited resources for optimal allocation and use to enable themharness the best productivity and income.

\section{REFERENCES}

- Gangwar, L. S.,(1994). Technological Advancements and its Implications on Sustainable Agriculture- A Case Study of Nainital Tarai of Uttar Pradesh. Ph.D. thesis. Department of Agricultural Economics, Institute of Agricultural Sciences, Banaras Hindu University, Varanasi, India.

- Gautam, K., Sen C and Prakash J. (2015).Optimization of Employment and Income of Agricultural labourers through crop enterprise: Linear Programming Approach, Progressive Research-An International Journal, Volume 10 Special Part III, pp. 1465-1471.

- Kumari, M., Singh, O.P. and Meena, D.C.,(2017). Optimizing cropping pattern in Eastern UttarPradesh usingSen's Multi Objective Programming Approach, Agricultural Economics Research Review, Vol. 30 (No.2)

- Kushwaha, S. , J.E.Ochi, E.O. Adeleke, and Chandra Sen,(1998a). Estimating animal waste required for use as fertilizer: A linear programming simulation approach. Journal of Agricultural Development and Policy, Vol.10 (1), 80-88

- Kushwaha, S.,(1992b). Resource Allocation for Alternative Farming System in Varanasi District, U.P.. Ph.D. thesis, Ph.D thesis, Department of Agricultural Economics, Institute of Agricultural Sciences, Banaras Hindu University, Varanasi, India

- Memariani, A.,(1993). Some Studies in Multiple Criteria Decision Making in CRISP, RANDOM and FUZZY Environment. Ph.D. thesis, Department of Mathematics, Banaras Hindu University. Varanasi, India.

- Sen, C. (1983) A new approach to Multi-objective Rural Development Planning. The Indian Economy Joumal Vol.30 No.4.91-96.

- Sen, C. and D.K.Painuli, (1984). An integrated land use planning for minimizing soilerosion in the hills of Uttar Prades h. Indian Journal of Soil Conservation, 12(1), 1-4.

- Sen, Chandra and P.P. Dubey, (1994). Resource use planning in Agriculture with single and Multi-objective programming approaches (A comparative study). Journal of Scientific Research, 44, 75-81

- Singh, V. K., (2002). Agricultural Development and Environmental Pollution- A Case Study of District Varanasi. Ph.D. thesis Department of Agricultural Economics, Institute of Agricultural Sciences, Banaras Hindu University, Varanasi, India 